\title{
Peningkatan Keterampilan Mengukur Panjang Benda Melalui Penggunaan Media Video Pada Peserta Didik Kelas II MI Al-Fatah Dimong
}

\author{
Ni'matul Khoiriyah \\ Universitas Sebelas Maret \\ nicmachoir5043@gmail.com
}

\section{Article History}

received 30/4/2021

revised 30/5/2021

accepted 30/6/2021

\begin{abstract}
In the learning process the use of video media can improve the skills of measuring the length of objects. The purpose of this study was to improve the skills of measuring the length of objects through the use of video media for class II students of MI Al Fatah Dimong in the 2020/2021 academic year. This research is a classroom action research conducted in two cycles. The research subjects were students of class II MI Al Fatah Dimong, totaling 12 children. Data collection techniques used are observation, tests, and documentation. The validity of the data used is source triangulation and technique triangulation. which involves several sources to collect data. The result of the research shows that the percentage of the skill in measuring the length of the object in pre-action is 33\%, in the first cycle it increases to $58 \%$ in the second cycle, it increases to $90 \%$. The conclusion of the study is that through the use of video media can improve the skills of measuring the length of objects in class II students of MI Al Fatah Dimong for the 2020/2021 academic year.
\end{abstract}

Keywords: Video Media, the skill of measuring the length of objects.

\begin{abstract}
Abstrak
Pada proses pembelajaran penggunaan media video dapat meningkatkan keterampilan mengukur panjang benda. Tujuan penelitian ini untuk meningkatkan keterampilan mengukur panjang benda melalui penggunaan media video pada siswa kelas II MI Al Fatah Dimong tahun ajaran 2020/2021. Penelitian ini adalah penielitian tindakan kelas yang dilaksanakan dalam dua siklus. Subjek penelitian adalah siswa kelas II MI Al Fatah Dimong yang berjumlah 12 anak. Teknik pengumpulan data yang digunakan adalah observasi, tes, dan dokumentasi. Validitas data yang digunakan adalah tringulasi sumber dan tringulasi teknik. yaitu melibatkan beberapa sumber untuk mengumpulkan data. Hasil penelitian menunjukkan bahwa persentase nilai ketuntasan keterampilan mengukur panjang benda pada pratindakan adalah $33 \%$, pada siklus satu meningkat menjadi $58 \%$ pada siklus dua semakin meningkat menjadi $90 \%$. Kesimpulan pada penelitian adalah melalui penggunaan media video dapat meningkatkan keterampilan mengukur panjang benda pada peserta didik kelas II MI Al Fatah Dimong tahun ajaran 2020/2021

Kata kunci: Media Video, keterampilan mengukur panjang benda.
\end{abstract}




\section{PENDAHULUAN}

Dalam perkembangan dunia pendidikan, peran mengajar dan pembelajaran sangatlah penting,terutama bagi siswa-siwi di sekolah. Karena, melalui kegiatan mengajar dan pembelajaran proses pendidikan berlangsung dengan baik.Oleh karena itu, dunia pendidikan akan berjalan dengan baik apabila kegiatan mengajar serta pembelajaran di sekolah diperhatikan dan dicermati..Salah satunya adalah dengan memahami tentang inovasi pembelajaran yaitu penggunaan media yang digunakan dalam proses penyampaian materi pelajaran kepada peserta didik di sekolah.

Guru merupakan komponen utama di dalam pendidikan. Tugas utama guru adalah membimbing peserta didik di sekolah dan membantu menyampaikan materi pembelajaran kepada anak didik agar anak didik mudah dalam belajar. Pada masa pandemi pembelajaran dilakukan dengan cara belajar jarak jauh. Maka peserta didik dituntut belajar mandiri di rumah dengan dipandu guru melalui belajar jarak jauh. Guru dituntut untuk menciptakan pembelajaran yang inovatif dan menarik, yang memudahkan peserta didik untuk memahami materi yang diajarkan. Menurut Anindyawati (2014:2) guru harus menggunakan inovasi media pembelajaran yang sesuai dengan materi pembelajaran yang diajarkan dan karakteristik siswa. Dengan menggunakan media pembelajaran yang sesuai diharapkan dapat meningkatkan kualitas proses belajar-mengajar.

Permasalahan dalam dunia pendidikan saat ini, yaitu pada kondisi jarak jauh atau belajar di rumah peserta didik mudah bosan, di dalam belajar, peserta didik juga merasa kesulitan dalam memahami materi pembelajaran sehingga pemahaman peserta didik tentang materi matematika bab pengukuran sangat sulit. Di dalam kondisi yang seperti itu guru harus bisa menerapkan pembelajaran yang inovatif dan menarik perhatian peserta didik untuk belajar, guru juga di tuntut untuk menyiapkan media pembelajaran yang mudah di pahami oleh peserta didik.

Pada zaman sekarang, perkembangan ilmu pengetahuan dan teknologi sangat pesat, semua orang dapat memperoleh informasi yang luas dengan cepat dan mudah dari berbagai sumber dan tempat. Hal tersebut merupakan keterampilan yang harus dimiliki oleh peserta didik yaitu mampu mencari, memilih dan mengelola informasi seabagi bekal untuk menggali informasi dan pengetahuan yang lebih luas. Menurut Nurfitria (2018:5) matematika merupakan pembelajaran yang berfungsi mengembangkan kemampuan menghitung, mengukur, menurunkan dan menggunakan rumus dalam masalah kehidupan sehari-hari. Matematika diperlukan di dalam kehidupan sehari-hari. materi yang harus dikuasai peserta didik didalam matematika yaitu pengukuran dan geometri, aljabar, dan trigonometri. Salah satu kompetensi yang harus dikuasai peserta didik adalah pengukuran karena didalam kegiatan sehari-hari tidak lepas dengan peristiwa mengukur. Pengukuran merupakan penentuan besaran, dimensi, atau kapasitas, biasanya terhadap suatu standar atau satuan ukur. Menurut Maftukhah (2015:3) Pembelajaran pengukuran merupakan pembelajaran yang penting peserta didik, karena dengan memahami pengukuran peserta didik dapat menghitung panjang suatu benda dalam kehidupan sehari-hari. Belajar mengukur juga dapat melatih siswa untuk berpikir pada tingkat yang lebih tinggi seperti pemecahan masalah.

Berdasarkan data empirik di lapangan masih banyak peserta didik kelas II MI AL FATAH yang belum menguasai materi pengukuran panjang benda. Kurangnya kemampuan mengukur panjang bendapeserta didik dalam pembelajaran matematika masih rendah. Berdasarkan Keterampilan observasi yang telah di lakukan oleh guru kelas II di MI AL FATAH pada hari sabtu, tanggal 21 November 2020 diketahui bahwa pembelajaran Matematika materi pengukuran kelas II nilai yang harus ditempuh adalah 70, Keterampilan penilaian pada kompetensi dasar menggunakan alat ukur dalam pemecahan masalah sekitar, peserta didik menunjukkan ada yaitu 4 dari 12 peserta didik yang mampu mencapai KKM, sedangkan sisanya sebesar 8 peserta didik masih 
belum mencapai KKM yang telah ditetapkan. Dari penilaian tersebut dapat diketahui bahwa kemampuan mengukur dengan benar dan tepat khususnya materi pengukuran panjang relatif kurang. Banyak peserta didik yang masih belum mampu menggunakan alat ukur khususnya alat ukur baku seperti penggaris.

Hal tersebut disebabkan karena pengalaman belajar matematika yang masih abstrak, dan kurangnya variasi strategi pembelajaran yang dilakukan guru saat mengajar sehingga terkesan monoton, kurangnya penerapan langsung (praktik) saat pembelajaran. Jika hal ini tidak segera ditangani maka peserta didik akan tidak dapat mengunakan alat ukur satuan panjang dengan tepat dan akurat serta ditakutkan mereka tidak dapat membaca skala yang ada di penggaris, meteran, atau alat ukur panjang lainnya, peserta didik tidak dapat menerapkannya dalam kehidupan seharihari, dan akan tertinggal untuk materi selanjutnya yang akan berhubungan dengan alat ukur ataupun pengukuran.

Mengingat kemampuan peserta didik dalam mengukur masih kurang, sangat di perlukan strategi dan cara dalam mengajarkan peserta didik untuk melakukan pengukurang suatu panjang benda dengan benar. Menurut Yunita, wijayanti.dkk (2017:2) guru harus bisa meningkatkan mutu pembelajaran karena terlibat langsung dalam upaya membina dan mengembangkan kemampuan peserta didik. Penggunaan media pembelajaran sangat berpengaruh dalam penyampaian materi karena dengan menggunakan media pembelajaran guru dapat menyajikan materi yang menarik sehingga minat belajar peserta didik dapat meningkat dan peserta didik mudah memahami pelajaran. Dan keterampilan belajarnya.

Salah satu media yang digunakan dalam pembelajaran yang dapat meningkatkan pemahaman dan motivasi belajar peserta didik adalah media Video pengukuran. Media Video terbukti dapat meningkatkan keterampilan mengukur.hal ini di buktikan dengan adanya penelitian terdahulu yang dilakukan oleh Istiqomah dengan judul Penggunaan Media Audio Visual Untuk Meningkatkan Keterampilan Hasil Belajar Siswa Pada Pembelajaran Matematika Kelas IV Di MI Almunawwarah Kota Jambi dengan dengan kesimpulan media video pembelajaran dapat meningkatkan keterampilan belajar Matematika.

Media Video pengukuran merupakan salah satu sarana alternative dalam melakukan proses pembelajaran berbasis teknologi. Video pengukuran pembelajaran dapat digunakan sebagai sarana alternative dalam mengoptimalkan proses pembelajaran, dikarenakan beberapa aspek yaitu mudah dikemas dalam proses pembelajaran, lebih menarik untuk pembelajaran, dapat diperbaiki setiap saat. Media pembelajaran video dapat digunakan sebagai alat untuk memperjelas materi pembelajaran dan memberikan penjelasan konsep dari yang abstrak menjadi kongkrit, selain itu media video pengukuran ini juga dapat meningkatkan pemahaman peserta didik dalam belajar karena peserta didik tidak hanya mendengarkan tetapi juga dapat melihat materi yang ditayangkan dengan lebih bervariasi Rizal fakhrul (2014:3). Dengan permasalahan yang di jelaskan , untuk menigkatkan kemampuan peserta didik dalam mengukur panjang benda, peneliti akan melakukan penelitian tindakan kelas dengan mengambil judul "Peningkatan Keterampilan Mengukur panjang benda melalui Penggunaan Media Video Pada Peserta didik Kelas II MI Al-Fatah Pada Tahun 2020/2021".

\section{METODE}

Penelitian ini merupakan jenis penelitian tindakan kelas dengan menggunakan desain penelitian model Kemmis dan Mc. Taggart (dalam Arikunto, 2013:138-140) dengan alur perencanaan, pelaksanaan, observasi dan refleksi (Suharsimi; 2007:107). Penelitian ini dilaksanakan pada semester genap tahun ajaran 2020/2021 di MI AlFatah Dimong Kecamatan Madiun Kabupaten Madiun yang terdiri dari 12 siswa. Objek penelitian adalah keteramplan mengukur panjang benda pada peserta didik. Teknik 
pengumpulan data menggunakan Tes ,observasi, dokumentasi.. Data dianalisis secara deskriptif dan disajikan dalam bentuk tabel dan grafik. Indikator keberhasilan penelitian yaitu kriteria ketuntasan minimal keterampilan membaca puisi mencapai 70 dan secara klasikal mencapai $\geq 85 \%$ (Trianto: 2010:241).

\section{HASIL DAN PEMBAHASAN}

Berdasarkan pelaksanaan tindakan selama 2 siklus, diperoleh data bahwa keaktifan belajar siswa mengalami peningkatan. Peningkatan keterampilan mengukur panjang benda meningkat, diketahui dengan menerapkan media pembelajaran video. Hasil observasi terhadap penggunaan video dalam meningkatkan keterampilan mengukur panjang benda peserta didik dapat dilihat pada diagram berikut:

\begin{tabular}{|c|c|c|}
\hline Keterangan & Siklus I & Siklus II \\
\hline Rata-rata & 73 & 85 \\
\hline Presentase & $51 \%$ & $90 \%$ \\
\hline Kategori & Cukup & Baik \\
\hline
\end{tabular}

Berdasarkan tabel di atas persentase hasil aktivasi belajar pada keterampilan mengukur panjang benda pada peserta didik dari siklus pertama hingga kedua mengalami peningkatan. Siklus pertama rerata skor aktivitas peserta didik adalah 73 yang termasuk dalam kategori cukup. Siklus kedua mengalami kenaikan rerata sebesar 73 dari menjadi 85. Rerata tersebut termasuk dalam kategori baik. Secara prsesentase aktivitas belajar peserta didik mencapai 51\% dan meningkat pada siklus II dengan rata-rata persentase nilai Aktivitas peserta didik adalah $90 \%$ dan masuk pada kriteria sangat baik.

Pembelajaran berlangsung secara baik pada setiap pelaksanaan tindakan. Peserta didik antusias dan senang dalalm pembelajaran dengan menggunakan video. Meskipun pada pelaksanaan tindakan siklus I ada beberapa peserta didik yang belum aktif ketika diskusi kelompok, menyampaikan pendapat atau menjawab pertanyaan dari guru setelah memperhatikan media video. Pada siklus II ada peningkatan keterampilan mengukur panjang berdasarkan penilaian sudah meningkat, kegiatan pembelajaran tampak hidup dan semangat, karena siswa aktif dan termotivasi belajar cara mengukur panjang benda dengan benar dengan menggunakan video. Peningkatan Aktivitas belajar peserta didik tersebut terjadi setelah guru mengembangkan media dan materi dengan menambahkan beberapa permasalahan, video dan gambar yang berkitan dengan pengukuran. Dengan demikian, aktivitas peserta didik selama tindakan siklus I sampai dengan siklus II terus mengalami peningkatan.

Tabel II Peningkatan keterampilan mengukur panjang benda pada peserta didik diketahui dari hasil tes siswa pada siklus I dan II sebagai berikut:

\begin{tabular}{llll}
\hline \multicolumn{1}{c}{ Keterangan } & & Nilai & \\
\hline & Pra Siklus & Siklus I & Siklus II \\
\hline Jumlah & 800 & 888 & 1050 \\
\hline Rata-Rata & 67 & 74 & 88 \\
\hline Nilai Tertinggi & 76 & 88 & 93 \\
\hline Tuntas KKM & 4 siswa & 7 Siswa & 11 Siswa \\
\hline Belum Tuntas KKM & 8 siswa & 5 Siswa & 1 Siswa \\
\hline Presentase KKM & $34 \%$ & $58 \%$ & $91 \%$ \\
\hline
\end{tabular}


Dari Tabel diatas menunjukan data nilai keterampilan mengukur siswa dari pra siklus, siklus 1 dan siklus II. Keterampilan mengukur siswa dari prasiklus ke siklus I, siklus II sudah meningkat. Hal tersebut dapat dilihat dari nilai rata-rata kelas pada prasiklus memperoleh rata-rata 66. Peningkatan terjadi pada tahap siklus I yaitu keterampilan mengukur peserta didik memperoleh nilai rata-rata 74. Pada siklus II nilai rata-rata mengalami peningkatan lagi yaitu memperoleh rata-rata 88 (baik) dan presentase ketuntasan belajar yaitu presentase ketuntasan pada prasiklus $33 \%$ (sangat kurang), meningkat menjadi 58\% (cukup) pada siklus I, kemudian meningkat lagi menjadi $91 \%$ (baik) pada siklus II. Dari penjelasan di atas peningkatan keterampilan mengukur panjang benda dapat dilihat pada diagram dibawah ini!

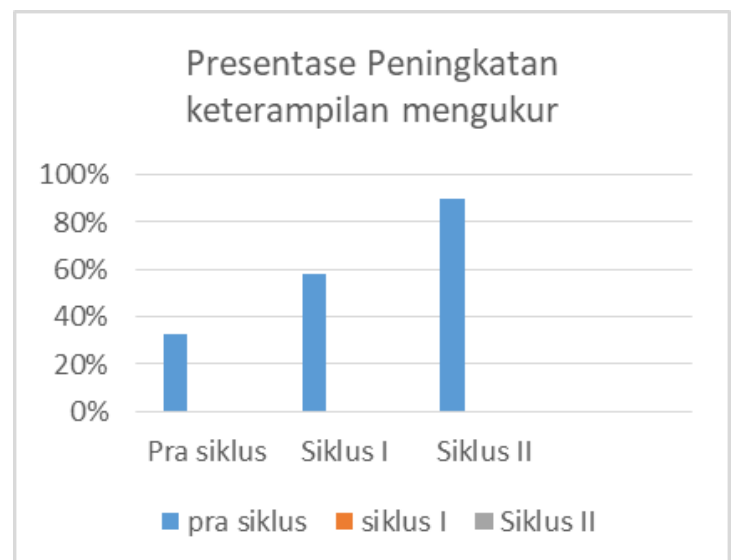

\section{Gambar 1 presentase peningkatan keterampilan mengukur panjang benda}

Dari diagram di atas, presentase nilai rata-rata Kelas II pada keterampilan mengukur panjang benda pada tahap prasiklus memperoleh presentasi nilai rata-rata yaitu $33 \%$ artinya sangat kurang yaitu dari 12 siswa hanya 4 siswa yang tuntas, 8 siswa tidak tuntas. Hal tersebut disebabkan karena masih banyak siswa yang belum mengenal fungsi alat ukur dengan benar, belum faham cara mengukur dan membaca alat ukur dengan benar dan tepat. Presentase mengalami peningkatan pada siklus I mencapai presentase 58\% (cukup) artinya ada 7 siswa yang lulus KKM sedangkan yang 5 siswa belum lulus KKM, hal ini disebabkan karena masih ada beberapa siswa yang belum faham cara mengukur panjang benda dengan benar dan membaca hasil pengukuran dengan tepat, dan mengubah satuan alat ukur dengan benar. Hal tersebut menyebabkan ketuntasan nilai keterampilan mengukur panjang benda siswa ada yang tidak tuntas. Pada siklus II terjadi peningkatan lagi yaitu memperoleh prsesentase 91\% artinya dari 12 siswa ada 11 siswa siswa yang tuntas KKM da nada 1 siswa yang belum tuntas KKM. Ada satu yang belum tuntas di sebabkan siswa tersebut masih belum menguasai cara membaca angkat ketika mengukur dengan tepat.

Penggunaan video dapat meningkatkan keterampilan mengukur panjang benda mata pelajaran matematika Siswa Kelas II MI Al Fatah Dimong,dengan menggunakan video di dalam pembelajaran peserta didik lebih semangat dalam mengikuti pembelajaran, ceria, responsif, aktif, saling bekerjasama dan peserta didik juga tertarik, senang dengan media video di dalam pembelajaran sehingga peserta didik mudah untuk memahami dan mengingat materi. Secara klasikal keterampilan mengukur panjang benda pada siswa kelas II MI Al fatah Dimong sudah meningkat sesuai penelitian terdahulu yang dilakukan oleh Istiqomah (2020) yaitu media video pembelajaran dapat meningkatkan keterampilan belajar pengukuran $\mathrm{Hal}$ ini di dukung oleh pendapat menurut Rusman (2013 : 162) berpendapat bahwa media video merupakan alat yang memungkinkan seseorang mengerti dan memahami sesuatu dengan mudah sehingga mampu mengingatnya dalam jangka waktu yang cukup lama 
sehingga dapat meningkatkan keterampilan belajar siswa terutama dalam materi pengukuran.

Berdasarkan uraian penelitian dapat disimpulkan bahwa penggunaan media video dapat meningkatkan keterampilan mengukur panjang benda pada peserta didik kelas II MI Al Fatah Dimong.

\section{SIMPULAN}

Berdasarkan hasil penelitian dapat disimpulkan bahwa Penggunaan video dalam peningkatan keterampilan mengukur panjang benda telah berjalan dengan baik. Hal ini dibuktikan dengan meningkatnya presentase nilai aktivitas siswa pada sikus I sebesar $50 \%$ (cukup) menjadi $91 \%$. Dengan nilai rata-rata pada siklus I 73(Cukup) meningkat di siklus II menjadi 85 (baik). Peningkatan keterampilan mengukur panjang benda melalui penggunaan media video pada peserta didik kelas II MI Al-fatah pada tahun 2020/2021 mengalami peningkatan setelah diterapkan penggunaan media video pada proses pembelajarannya. Nilai rata-rata kelas siswa mengalami peningkatan pada siklus II. Hal ini dibuktikan dengan meningkatnya hasil nilai keterampilan siswa pada pra siklus rata-rata nilai 66 meningkat lagi di sikus I sebesar 74 (cukup) dan meningkat lagi menjadi 88 (baik) pada siklus II. Sedangkan persentase ketuntasan belajar keterampilan mengukur panjang siswa secara klasikal mengalami peningkatan dari pra siklus ketuntasan belajarnya $33 \%$ menjadi $58 \%$ pada siklus I dan meningkat lagi menjadi $90 \%$ pada siklus II. keterampilan mengukur panjang siswa mengalami peningkatan dengan menggunakan media video.

Peneliti memberikan saran beberapa berikut bahwa Selama pembelajaran diharapkan guru memakai media yang menarik yaitu menggunakan video pembelajaran sebagai media ketika mengajar di kelas. Media video memiliki daya tarik yang tinggi sehingga dapat memotivasi siswa dalam mengikuti pembelajaran di kelas sehingga dapat menunjang pembelajaran agar lebih optimal. Guru dapat mengemas video dengan baik sesuai dengan materi yang akan diajarkan, supaya dapat menghidupkan suasanan kelas terutama pada mata pelajaran Matematika karena mata pelajaran tersebut termasuk kategori mata pelajaran yang dirasa sulit dan abstrak.

\section{DAFTAR PUSTAKA}

Ainina, I. A. (2014). Pemanfaatan Media Audio Visual Sebagai Sumber Pembelajaran Sejarah. Indonesian Journal of History Education, 3(1).

Anindyawati, (2014) "Pemanfaatan Media Video Pembelajaran Untuk Meningkatkan Hasil Belajar Ips Pada Siswa Kelas Iv Sdn Babatan I/456 Surabaya”. Jurnal Ilmiah Pendidikan Guru Sekolah Dasar.

Anitah, Sri. (2008). Media Pembelajaran. Surakarta : UNS Press.

Arikunto, Suharsimi. (2010). Prosedur Penelitian Suatu Pendekatan Praktik. Jakarta: PT. Rineka Cipta.

Indriana, Dina. (2011). Ragam Alat Bantu Media Pengajaran. Yogyakarta : Diva Press. Istiqomah, (2020) Penggunaan Media Audio Visual Untuk Meningkatkan Hasil Belajar Siswa Pada Pembelajaran Matematika Kelas IV Di Mi Almunawwarah Kota Jambi. http://repository.uinjambi.ac.id/5948/

Maftukhah (2015) "Peningkatan Hasil Belajar Matematika Materi Pengukuran (Satuan Panjang) Melalui Metode Problem Based Learning Pada Siswa Kelas IV Mi Keputon Kecamatan Blado Kabupaten Batang Tahun Ajaran 2015/2016". http://e

repository.perpus.iainsalatiga.ac.id/245/1/Anny\%20Maftukhah_11511063.pdf

Miftahussurur,(2016) "Peningkatkan Hasil Belajar Menggunakan Media Video Pembelajaran Pada Kompetensi Dasar Memelihara/Servis Sistem Pendingin Mesin" Jurnal Pendidikan Teknik Mesin. 
Volume 9 Nomor 1 Tahun 2021

Nurfitriah (2018) "Peningkatan Keterampilan Mengukur panjang bendaMata Pelajaran Matematika Melalui Strategi Contextual Teaching and Learning Kelas III MI Annahdliyin Dukuh Tengah Buduran Sidoarjo" .

Rusman. (2013). Belajar dan Pembelajaran Berbasis Komputer, Mengembangkan Profesionalisme Abad 21. Bandung : CV. Alfabeta.

Sugiyono. (2015). Metode Penelitian Kombinasi (Mixed Methods). Bandung: Alfabeta Triyono. (2013). Metodologi Penelitian Pendidikan. Yogyakarta : Ombak.

Yunita, wijayanti. (2017) "Pengaruh Media Video Pembelajaran Terhadap Hasil Belajar Ipa Ditinjau Dari Keaktifan Siswa”. Jurnal IImiah Pendidikan Guru Sekolah Dasar. 